\title{
Eugène (Eugeniusz) Zaleski, 1918-2001
}

Eugène Zaleski died in Paris on 24 November 2001. He was preceded in death by his wife of nearly fifty years, Isabelle nee Cotton. Caught up in the turmoil of time and place, Zaleski was born on 27 August 1918 in Lwów, which was still under Habsburg rule. In resurrected Poland he studied iura at the local, and renowned, Jan Kazimierz University, graduating in 1940, under Soviet occupation. After the Soviet occupants were replaced by the Nazis in 1941, Zaleski joined the Polish underground (ZWZ, and subsequently AK, the Home Army). In May 1943 he was arrested and imprisoned in the infamous concentration camps, Auschwitz and Mauthausen. The American troops freed him in May 1945. Like so many others, Zaleski did not return to communist Poland; his hometown had been annexed by the Soviets anyway. Instead he enlisted in the Polish Army Corps, a part of the Allied Forces then in France. Demobilized in 1948, he settled there. Coming from a social milieu in which children were taught French from the earliest age, Eugène Zaleski found the country congenial. He married, pursued further studies at the University of Paris, and, over the years, established himself as one of the leading scholars of the Soviet Union.

In 1951, Zaleski joined the staff of the prestigious French research organization, Centre National de la Recherche Scientifique (CNRS), where he advanced to the position of director of research in 1968. He also became the editor of the Revue de l'Est (later renamed Revue d'Études Comparatives Est-Ouest), a quarterly devoted to Soviet and east European affairs. The importance of the Rerne greatly increased under his editorship. In addition to his administrative and editorial duties and his extensive research activities, Zaleski took on teaching obligations, lecturing and conducting seminars at several French institutions, including the universities Paris-Dauphine, Paris-Sorbonne, and Aix-Marseille as well as the École des Sciences Politiques. His role in educating several generations of French sovietologists cannot be overestimated. In addition, there were engagements abroad, especially in the United States and England: at the Harvard Russian Center, Stanford's Hoover Institution, Oxford's St. Antony's College, and the University of Birmingham. An early association with the University of Virginia (1962-63) was particularly productive.

There were also numerous short-term commitments. Zaleski often participated in conferences and colloquia, whether organized by the French government, the Organization for Economic Cooperation and Development (OECD), or the North Atlantic Treaty Organization (NATO). For twenty years he worked closely with Warren G. Nutter and Renato Mieli to organize the annual Centro studi sui sistemi socio-economici dell'est (CESES) seminars held in Italy, at the time a prime forum for east-west discussions.

Zaleski's earliest published work consisted of a two-volume source book on the Russian labor movement and socialism: Mouvements ouvriers et socialistes-Chronologie et Bibliographie-La Russie, I: 1725-1907 and II: 1908-1919 (Paris, 1956 and 1957). This was followed by his doctoral dissertation on trade in the Danubian basin: Les courants commerciaux de l'Europe danubienne au cours de la première moitié du $X X^{\circ}$ siècle (Paris, 1962). The attention to detail and orderly presentation that were his trademark were already evident in these works. They were also characteristic of the large scholarly output of later years. Books, journal articles, reports, and memoranda, most in French, followed. Among his works that have been translated into English are Planning Reforms in the Soviet Union, 19621966 (Chapel Hill, 1967), Planning for Economic Growth in the Soviet Union, 1918-1932 (Chapel Hill, 1971), and Stalinist Planning for Economic Grozth, 1933-1952 (Chapel Hill, 1980 ). The last two are generally recognized as seminal. His contributions to the study of Soviet science policy and east-west technology transfers, published by $O E C D$, are also noteworthy, as are his sundry writings on the Soviet budget, finances, prices, and trade. The distinguishing mark of his work was a stark empiricism. His orientation was historical: the study of a particular kind of society, and its institutions, in their quantitative dimensions. With little if any theorizing, and statistics kept to a minimum, the figures were meant to speak for themselves and to debunk the myths of communist central planning. In his

Slavic Reviewu 61, no. 3 (Fall 2002) 
own down-to-earth and matter-of-fact way, Eugène Zaleski ranks among the classic sovietologists. He also testifies to the vitality of the central European academic tradition of which he was a product.

Eugène Zaleski's expertise and advice were widely sought. He gave of himself prodigiously, collaborating with various organizations, notably France's Commissariat du Plan, OECD, and NATO. He was affiliated with a number of professional groups, including the Association Française des Sciences Économiques and the Mont Pelerin Society.

Notwithstanding the overload of professional activities, Zaleski found time for public service. Upon his release from the Nazi camp, he assumed leadership of the local Polish Committee in Linz. Later, in his adopted country, France, he presided for many years over the Société Historique et Littéraire Polonaise, serving also as the director of the venerable Bibliothèque Polonaise de Paris, which was founded over a century and a half ago by Prince Adam Czartoryski. He was also a member of Polish veteran and political prisoners organizations in France. A very busy man, Zaleski hardly ever passed up an opportunity to get involved in matters that seemed worthy of his attention. Neither, reportedly, did he neglect an opportunity to ski and play tennis. He was a good friend to many and will be greatly missed. May he rest in peace.

ANDRZE] BRZESKI University of California, Davis

Henri Dunajewski Université Aix-Marseille, Aix-en-Provence

Acôta Gueullette Centre National de la Recherche Scientifique

JoHN H. MOORE Grove City College, Grove, Michigan March 2002 